\title{
THE EFFECT OF CROSSING ON MEAT YIELD AND QUALITY OF WEANED LAMBS
}

\author{
D.Ružić-Muslić $^{1}$ M.P.Petrović ${ }^{1}$, M.M. Petrović ${ }^{1}$ Z.Bijelić ${ }^{1}$, V. Pantelić ${ }^{1}$, \\ P.Perišić ${ }^{2}$, V.Caro-Petrović ${ }^{1}$ \\ ${ }^{1}$ Institute for Animal Husbandry, Belgrade-Zemun, 11080 Zemun, Serbia \\ ${ }^{2}$ Faculty of Agriculture, University of Belgrade, 11080 Zemun, Serbia \\ Corresponding author: muslic.ruzic@.gmail.com \\ Original scientific paper
}

\begin{abstract}
This study examines the impact of two-breed (PXW) and threebreed (PxWxIDF) system of sheep crossing on the results in terms of yield and quality of meat of lambs, weaned at 60 days of age and fattened up to 120 days of age. Study was carried out on the experimental sheep farm of the Institute for Animal Husbandry, Belgrade-Zemun, and the following breeds of sheep were used for crossing: Pirot pramenka (P) Württemberg (W) and Ile de France (IDF). As maternal basis the Pirot Pramenka and two breed crosses were used, and as improvement breed - Ile de France rams. Pre-slaughter body mass of two-breed and three-breed crosses was: 32.63 and $34.48 \mathrm{~kg}$. Values of dressing percentage warm carcass with head and offal were: 59.0 and $58.4 \%$. The share of the category I meat on analogue treatments was: $37.07: 37.48 \%$, meat of category II: $33.98: 32.41 \%$, and the meat of category III $-28.69: 26.87 \%$. Meat to bone ratio was: $2.3: 1$ in twobreed crosses, whereas in the three-breed crosses it was 2.7:1. MLD surface was 11:49 and 11:45 $\mathrm{cm}^{2}$. Regarding the chemical and technological characteristics, there were no significant differences among the treatments $(\mathrm{P}>0.05)$.
\end{abstract}

dorsi (MLD)

Keywords: crossing, crosses, yield, meat categories, Musculus longissimus

\section{Introduction}

Analysis of sheep production systems in the world shows that in many countries slaughter lambs are crosses in $30-70 \%$ of cases (Mitić, 1984). This is understandable considering that the quickest and easiest way to improve growth performance and carcass quality is crossing (Kuchtik et al., 2012). To this end, different breeds and crossbreeding systems are used. In the system of crossing of two breeds of sheep only individual heterosis is used, while in the three-breed crossing systems, to the individual heterosis also the heterosis of the mother is added. When the four breed crossing of sheep is used, besides the aforementioned, with $100 \%$ also the sire heterosis is used. 
Basically, the phenomenon of heterosis is higher activity and stability of the biochemical processes that characterize the crosses, which leads to a better expression of some quantitative traits (fertility, growth, feed conversion) in crossbred F1 generation compared to the parents (Petrović, 2000).

In comparative fattening of Pramenka lambs and crossbred Pramenka $\mathrm{x}$ Wurttenberg aged 90 days (Rako et al., 1982), the crosses showed superiority in terms of slaughter traits, considering that they had achieved meat yield of $59.08 \%$ compared to the yield of Pramenka lambs of 56.66\%. Marinova (1989) has established that the yield of crossbred Ile de France $x$ Romanovska $x$ Polutankoruna, at the age of 90 days was $56.20 \%$, and the share of fat in three rib cut was $20.9 \%$.

Smajić et al. (2001) investigated the participation of muscle tissue in basic parts of the left carcass side of fattened lambs of following genotypes: PramenkaKupres strain, Merinolandschaf, Romanovska and Ile de France. The highest share of muscle tissue in the carcass side (59.51\%) was registered in four-breed crosses, which is consistent with the manifestation of the heterosis effect.

The aim of the present study was to compare the yield and meat quality of lambs-crosses of F1 generation: Pirotska Pramenka x Württemberg and Pirot Pramenka $\mathrm{x}$ Württemberg $\mathrm{x}$ Ile de France, weaned at 60 days of age and fattened up to 120 days of age.

\section{Material and methods}

Investigations were carried out on the experimental sheep farm of the Institute for Animal Husbandry, Belgrade-Zemun. The crosses of F1 generation were used for testing: Pirot Pramenka $x$ Württemberg $(\mathrm{P} \times \mathrm{W})$ and Pirot Pramenka $\mathrm{x}$ Württemberg $\mathrm{x}$ Ile de France $(\mathrm{P} \times \mathrm{Wx}$ IDF), weaned at 60 days of age and fattened up to 120 days of age. The group feeding of animals with forage mixtures was ad libitum, while the limited amount of hay was equally distributed. At the end of the experiment, for the purpose of determination of the yield and quality of meat, a total of 18 animals were sacrificed (9 from each group). Dressing percentage was calculated from the ratio of pre-slaughter body mass of lambs and warm carcass weight with head and offal, and the mass of cooled carcasses without offal. The left carcass sides were cut into major parts and their masses were recorded. Share of tissues in carcass (morphological structure) was investigated in a three rib cut $(9,10$ and $11 \mathrm{rib})$, by dissection and measurement of muscle, fat, bone and connective tissues. In the chemical analysis of the MLD samples the following was determined: the total water content (\%) by drying at a temperature of $105^{\circ} \mathrm{C}$; the content of intramuscular fat by extraction with ether in Soxlet device content of total nitrogen substances by micro-method according to Kjeldahl and ash content by burning of the sample at $550^{\circ} \mathrm{C}$ to constant mass. Of the important 
technological properties of meat the following were determined: the loss of mass during cooking heat treatment $\left(10 \mathrm{~min}\right.$ at $\left.90^{\circ} \mathrm{C}\right)$ and roasting $(8$ minutes at 190 $200^{\circ} \mathrm{C}$ ), i.e. cooking loss and roasting loss. Statistical processing of the data was performed using programs Stat.Soft, Inc. (2003) STATISTICA (data analysis software system), version 6 using standard mathematical-statistical methods.

\section{Results and Discussion}

The average values of the pre-slaughter body mass and carcass yields of crosses are shown in table 1 . Three-breed crossbreds reached by $5.36 \%$ higher final body mass compared to the two breed-crosses, which was confirmed statistically (P $<0.01)$. The differences found in the yield ranged within the limits of random deviations $(\mathrm{P}>0.05)$, which means that the system of crossing had no significant effect on the studied trait, which can be explained by similar intensity of growth of crosses. The results are in agreement with results of Kuchtika et al. (2012) who have examined the physical and chemical characteristics of meat from two groups of crossbred animals (50:50 Romanovska x Charolais) and (50:50 Romanovska x Suffolk) and concluded that the crossing had no significant effect on yield of carcasses. Also, Zapletal et al. (2010) and Kuchtik and Horak (2001) have suggested that genotype of lambs does not affect the value of dressing percentage. Explanation for this phenomenon lies in the fact that genotypes with similar growth potential, subject to the same nutritive treatment that is sufficient for its exposure, give similar results in terms of meat. Factors influencing higher variability of the yield and quality of meat, are age and weight of the animals before slaughter (Petrović P. M, 1999, 2000).

Table 1. The average values of mass and carcass yield

\begin{tabular}{|l|c|c|c|}
\hline Studied traits & PxW & P x W x IDF & P \\
\cline { 2 - 4 } & $\mathrm{x} \pm \mathrm{Sd}$ & $\mathrm{x} \pm \mathrm{Sd}$ & \\
\hline Pre-slaughter body mass, kg & $32.63 \pm 6.90$ & $34.48 \pm 2.57$ & $* *$ \\
\hline Mass of warm carcass with head and offal, $\mathrm{kg}$ & $19.10 \pm 4.23$ & $20.13 \pm 1.49$ & $\mathrm{~ns}$ \\
\hline $\begin{array}{l}\text { Dressing percentage of warm carcass with head and } \\
\text { offal,\% }\end{array}$ & $59.0 \pm 2.02$ & $58.40 \pm 0.26$ & $\mathrm{~ns}$ \\
\hline Mass of chilled carcass with head and offal, kg & $18.11 \pm 3.97$ & $19.40 \pm 1.41$ & $\mathrm{~ns}$ \\
\hline $\begin{array}{l}\text { Dressing percentage of chilled carcass with head and } \\
\text { offal, \% }\end{array}$ & $56.70 \pm 2.13$ & $56.28 \pm 0.62$ & $\mathrm{~ns}$ \\
\hline Mass of chilled carcass without head and offal, kg & $14.76 \pm 3.39$ & $16.12 \pm 1.06$ & $\mathrm{~ns}$ \\
\hline $\begin{array}{l}\text { Dressing percentage of chilled carcass without head } \\
\text { and offal,\% }\end{array}$ & $46.13 \pm 1.89$ & $46.77 \pm 0.62$ & $\mathrm{~ns}$ \\
\hline
\end{tabular}

PxW (two-breed crosses)

PxWxIDF (three-breed crosses) 
Table 2 shows the yield of meat per category. Share of category I meat (leg and loin) in the left carcass mass in two-breed and three-breed crosses was: 37.07 : $37.48 \%$. Meat of category II (back, shoulder, neck) was represented by: 33.98: $32.41 \%$. The relative share of category III meat (chest with forearm and lower leg) was: $26.69: 26.87 \%$. Realized differences were not statistically significant ( $\mathrm{P}>$ 0.05 ), which means that the system of crossing had no effect on carcass weight and the share of individual categories meat. Obtained results are consistent with the results of Rodriquez et al. (2011) stating that the crossing of breeds does not have any significant effect on the yield of meat of different categories.

Table 3. Meat yield according to categories

\begin{tabular}{|l|c|c|c|}
\hline Studied traits & PxW & P x W x IDF & $\mathrm{P}$ \\
\cline { 2 - 4 } & & & \\
\cline { 2 - 4 } & $\mathrm{x} \pm \mathrm{Sd}$ & $\mathrm{x} \pm \mathrm{Sd}$ & \\
\hline Mass of left carcass side, $\mathrm{kg}$ & $7.34 \pm 1.72$ & $8.04 \pm 0.53$ & $\mathrm{~ns}$ \\
\hline Leg,\% $\%$ & $28.39 \pm 2.28$ & $28.58 \pm 2.60$ & $\mathrm{~ns}$ \\
\hline Loin,\% & $8.68 \pm 0.66$ & $8.97 \pm 0.96$ & $\mathrm{~ns}$ \\
\hline Total category I meat & $37.07 \pm 2.42$ & $37.48 \pm 2.95$ & $\mathrm{~ns}$ \\
\hline Back,\% & $7.22 \pm 1.26$ & $6.99 \pm 1.08$ & $\mathrm{~ns}$ \\
\hline Shoulder,\% & $19.62 \pm 1.72$ & $18.98 \pm 2.42$ & $\mathrm{~ns}$ \\
\hline Neck,\% & $7.13 \pm 1.65$ & $6.63 \pm 0.78$ & $\mathrm{~ns}$ \\
\hline Total category II meat & $33.98 \pm 1.58$ & $32.41 \pm 2.85$ & $\mathrm{~ns}$ \\
\hline Chest with forearm,\% & $24.27 \pm 1.69$ & $22.55 \pm 3.39$ & $\mathrm{~ns}$ \\
\hline Lower leg,\% & $4.44 \pm 0.61$ & $4.32 \pm 0.23$ & $\mathrm{~ns}$ \\
\hline Total category III meat & $28.69 \pm 2.07$ & $26.87 \pm 3.36$ & $\mathrm{~ns}$ \\
\hline
\end{tabular}

Morphological composition of the carcass side is determined by the ratio of tissues in three rib sample, whose values are given in Table 4.

Table 4. Ratio of tissues in the three rib cut

\begin{tabular}{|c|c|c|c|}
\hline \multirow[t]{2}{*}{ Studied traits } & PxW & $\mathrm{P} \times \mathrm{W} \times \mathrm{IDF}$ & $\mathrm{P}$ \\
\hline & $\mathrm{x} \pm \mathrm{Sd}$ & $\mathrm{x} \pm \mathrm{Sd}$ & \\
\hline Mass of three rib cut, $g$ & $235.52 \pm 4.48$ & $257.48 \pm 3.75$ & ns \\
\hline Muscle tissue, $\%$ & $45.18 \pm 2.27$ & $41.86 \pm 3.96$ & $\mathrm{~ns}$ \\
\hline Fat tissue, $\%$ & $23.39 \pm 3.33$ & $29.97 \pm 5.04$ & $\mathrm{~ns}$ \\
\hline Connective tissue, $\%$ & $1.33 \pm 0.88$ & $1.06 \pm 0.40$ & $\mathrm{~ns}$ \\
\hline Bone tissue, $\%$ & $29.63 \pm 7.01$ & $26.84 \pm 5.65$ & $\mathrm{~ns}$ \\
\hline Meat (muscle + fat tissue ) : bone ratio & $2.3: 1$ & $2.7: 1$ & $\mathrm{~ns}$ \\
\hline
\end{tabular}

The relative proportion of muscle tissue in three rib cut of two-breed and three-breed crosses was: $45.18: 41.86 \%$, while of fat tissue it was: $23.39: 29.97 \%$. 
The crosses $\mathrm{P} \times \mathrm{W}$ x IDF obtained by $0.4 \mathrm{~kg}$ more meat per $\mathrm{kg}$ of bones compared with two breed crosses $(\mathrm{P} \times \mathrm{W})$. The differences were not statistically significant $(\mathrm{P}>0.05)$. Obtained results are in agreement with the results of Gutierrez et al. (2005) who studied the effects of crossing of several breeds of sheep Pelibuei, Pelibuei x Suffolk, Palibuei x Rambouillet and found that the shares of muscle tissue were 54.01 53.73, and 51.27\%, respectively, with no statistical significance.

Results of the examination of chemical and technological properties of Musculus longissimus dorsi (MLD) in crosses are presented in Table 5. The differences ranged within the limits of random deviations $(\mathrm{P}>0.05)$. Our findings are consistent with the results of Vacca et al. (2008), obtained in the study of the quality of meat of crossbred Mouflon x Sarda and Sarda x Sarda, who determined that there were no significant differences between the genotypes in respect to chemical properties of MLD. Also, Ripoll et al. (2012), examining the effect of breed on meat quality of lambs observed that sheep breed had no influence on the chemical composition of the meat. Water content ranged from 74.9 to $78 \%$, crude protein content from 19.5 to $24.1 \%$, and $1.1 \%$ ash. Our results concerning the technological properties (cooking loss and roasting loss) are similar to data quoted by Costa et al., (2009). Loss of weight due to cooking was $27.18-30.29 \mathrm{~g} / 100 \mathrm{~g}$ and was not influenced by the studied sheep genotypes. Differences in regard to cooking loss may come because of the difference in obesity, because it is expected in case of thicker muscles to have higher cooking loss (Esenbuga et al., 2009).

Table 5. Chemical and technological meat properties

\begin{tabular}{|c|c|c|c|}
\hline \multirow[t]{2}{*}{ Studied traits } & $\mathrm{P} \times \mathrm{W}$ & $\mathrm{P} \times \mathrm{W} \times \mathrm{IDF}$ & $\mathrm{P}$ \\
\hline & $\mathrm{x} \pm \mathrm{Sd}$ & $\mathrm{x} \pm \mathrm{Sd}$ & \\
\hline MLD surface, $\mathrm{cm}^{2}$ & $11.49 \pm 2.12$ & $11.45 \pm 3.89$ & $\mathrm{~ns}$ \\
\hline Water, \% & $75.33 \pm 1.14$ & $74.90 \pm 1.07$ & $\mathrm{~ns}$ \\
\hline Proteins, $\%$ & $21.18 \pm 1.26$ & $21.74 \pm 1.12$ & $\mathrm{~ns}$ \\
\hline Fat, $\%$ & $2.32 \pm 0.49$ & $2.25 \pm 0.55$ & $\mathrm{~ns}$ \\
\hline Mineral substances, $\%$ & $1.06 \pm 0.03$ & $1.12 \pm 0.09$ & $\mathrm{~ns}$ \\
\hline Cooking loss, $\%$ & $18.41 \pm 1.42$ & $19.15 \pm 1.52$ & $\mathrm{~ns}$ \\
\hline Roasting loss, $\%$ & $29.67 \pm 2.88$ & $30.35 \pm 3.15$ & $\mathrm{~ns}$ \\
\hline
\end{tabular}

In terms of quality of lamb meat, most studies indicate the lack of effect of breed (Navajas et al., 2008). This suggests that, although the genetic potential of the lambs determines to some extent the quality of meat, the breed is not necessarily the dominant factor, especially when the same nutritive treatment is applied. 


\section{Conclusion}

Based on the results of investigation of the system of crossing on yield and meat quality of weaned lambs, the following can be concluded:

Three-breed crossbreds F1 (P x W x IDF) compared to two breed crosses F1 ( $\mathrm{P} \times \mathrm{W})$ realized by $5.36 \%$ higher final body mass, which was confirmed statistically $(\mathrm{P}<0.01)$.

Values of the yield warm carcass with head and offal were as follows: $59.05 \%$ (for $\mathrm{P} \times \mathrm{W}$ crosses) and $58.4 \%$ ( $\mathrm{P} \times \mathrm{W} \times \mathrm{IDF}$ crosses), with no statistical significance.

Shares of category I meat in two-breed and three-breed crosses were: $37.07,37.48 \%$, respectively; of category II meat: 33.98 and $32.41 \%$, while the meat of third category accounted for 28.69 and $26.87 \%$.

The system of crossing had no effect on the surface, chemical and technological properties of MLD of lambs.

\section{Acknowledgment}

Research was financed by the Ministry of Education, Science and Technological Development, Republic of Serbia, project TR 31053.

\section{Uticaj sistema ukrštanja na prinos i kvalitet mesa odlučene jagnjadi}

D. Ružić-Muslić, M. P. Petrović, M. M. Petrović, Z.Bijelić, V. Pantelić, P. Perišić, V. Caro-Petrović

\section{Rezime}

U radu je ispitivan uticaj dvorasnog (PxW) i trorasnog (PxWxIDF) sistema ukrštanja ovaca na rezultate u pogledu prinosa i kvaliteta mesa jagnjadi zalučene sa 60 dana i tovljene do 120 dana uzrasta. Istraživanja su obavljena na eksperimentalnoj farmi ovaca Instituta za stočarstvo Beograd-Zemun, a za ukrštanje su korišćene sledeće rase ovaca: Pirotska pramenka (P), Virtemberg (W) i Ile de France (IDF).Kao materinska osnova korišćeni su Pirotska pramenka i dvorasni melezi, a kao oplemenjivači - ovnovi Ile de France. Ishrana grla krmnim smešama je bila grupna i po volji, dok je količina sena ograničena i ravnopravno distribuirana. Na kraju ogleda, radi utvrđivanja prinosa i kvaliteta mesa, izdvojeno je i žrtvovano ukupno 18 grla (po 9 iz svake grupe).Statistička obrada dobijenih 
podataka je izvršena koršćénjem programa Stat.Soft, Inc (2003) STATISTICA (data analysis software system), version 6 , primenom standardnih matematičkostatističkih metoda. Telesna masa pred klanje meleza iz dvorasnog i trorasnog sistema ukrštanja je iznosila: 32.63 i $34.48 \mathrm{~kg}$.Vrednosti randmana toplog trupa sa glavom i iznutricama su iznosile: 59.0 i $58.4 \%$.Udeo mesa I kategorije na analognim tretmanima je iznosio: 37.07 : $37.48 \%$, mesa II kategorije: 33.98 : $32.41 \%$, dok je meso III kategorije bilo zastupljeno sa $28.69: 26.87 \%$. Odnos mesa prema kostima je bio: 2.3:1 kod dvorasnih meleza, dok je kod trorasnih iznosio 2.7: 1. Površina MLD je iznosila 11.49 i $11.45 \mathrm{~cm}^{2} . U$ pogledu hemijskih i tehnoloških osobina, nije bilo značajnih razlika između ispitivanih tretmana $(\mathrm{P}>0.05)$.

\section{References}

COSTA R.G., BATISTA A.S.M., MADRUGA M.S., NETO S.G. QUEIROGA R.C.R.E., FILHO J.T.A. (2009): Physical and chemical characterization of lamb meat from different genotypes submitted to diet with different fibre contens. Small Ruminant Research, 81, 29-34

ESENBUGA N., MACIT M., KARAOGLU, M.,AKSAKAL V., AKSU M.I., YORUK M.A. (2009):Effect of breed on fattening performance, slaughter weight and meat quality characteristics of Awassi and Morkaraman lambs.Livestock Science, $123,255-260$

GUTIERREZ J., RUBIO M.S., MENDEZ R.D. (2005): Effects of crossbreeding Mexican Pelibuey sheep with Rambouillet and Sufolk on carcass traits. Meat Science, $70,1-5$

KUCHTIK J., ZAPLETAL D., ŠUSTOVA K. (2012): Chemical and physical characteristics of lamb meat related to crossbreeding of Romanov ewes with Suffolk and Charolais sires. Meat Science, 90, 426-430

KUCHTIK J.,HORAK F. (2001):Growth ability, carcass and meat quality of lambs of the German Long-wooled sheep and their crosses. Czech Journal of Animal Science, 46,439-448

MARINOVA P., ČARKOV P., VOJNOVA P. (1989): Postnatalno razvitie na muskulnite vlakna i mesadajnost na hibridni agneta, postaveni pri različen tip na hranene v rana uzrast. Životnovodnie nauki, XXVI, 3, 8-15

MITIĆ N. (1984): Ovčarstvo. Zavod za udžbenike i nastavna sredstva, Beograd, 508 pp.

NAVAJAS E.A., LAMBE N.R., FISHER A.V., NUTE G.R., BUNGER L., SIMM G. (2008): Muscularity and eating quality of lambs: Effects of breed, sex and selection of sires using muscularity measurements by computed tomography. Meat Science, 79, Issue 1, 105-112 
PETROVIĆ P.M., JOSIPOVIĆ S., ŽUJOVIĆ M., RUŽIĆ D., STRSOGLAVEC S., MARINKOV G. (1999): The influence of genotype on the yield and quality of lamb meat. Biotechnology in Animal Husbandry,3-4, 61-69

PETROVIĆ P.M. (2000): Genetika i oplemenjivanje ovaca. Naučna, Beograd, 365 RAKO A., MIKULEC K., KARAĐOLE M., ARAMBAŠIĆ A. (1982): O tovnim sposobnostima i klaničnoj kvaliteti jagnjadi pramenke i njezinih križanaca sa virtemberškom ovcom. Stočarstvo, 7-8, 36, 279-287

RIPOLL G., ALCADE M.J., HORCADA A., CAMPO M.M., SANÜDO C., TEIXEIRA A., PANEA B. (2012): Effect of slaughter weight and breed on instrumental and sensory meat quality of suckling kids. Meat Science, 92,Issue 1, $62-70$

RODRIQUES A.B., BODAS R., LANDA R.,LOPEZ-CAMPOS O.,MANTECON A.R., GIRALDEZ F.J. (2011): Animal performance, carcass traits and meat characteristics of Assaf and Merinox Assaf growing lambs. Livestock Science, volume 138, Issues 1-3, pages 13-19

SMAJIĆ A., ŠUVALIJA B., DIZDAREVIĆ F. (2001):Komparativni pregled učešća mišićnog tkiva u osnovnim dijelovima lijeve polutke utovljene jagnjadi četiri pasminska tipa. Savremena poljoprivreda, 20, 3-4, 347-349

StatSoft, Inc. (data analysis software system), version 6 (2003), www.statsoft.com. ZAPLETAL D., KUCHTIK J., DOBEŠ I. (2010):The effect of genotype on the chemical and fatty acid composition of the quadriceps femoris muscle in extensively fattened lambs. Archiv Tierzucht, 53, 589-599

VACCA G.M., CARCANQIU V., DETTORI M.L., PAZZOLA M., MURA M.C., LURIDIANA S., TILLOCA G. (2008): Productive performance and meat quality of Mouflon x Sarda and Sarda x Sarda suckling lambs. Meat Science, 80, Issue 2, 326-334. 